\title{
Indeks massa tubuh berhubungan dengan angka kejadian katarak
}

\author{
Tania Callista Maheswari Pangestu, ${ }^{1}$ Erlani Kartadinata ${ }^{2}$
}

\begin{abstract}
ABSTRAK
Diperkirakan sebanyak $42 \%$ kasus kebutaan di dunia yang disebabkan oleh katarak berasal dari Asia Tenggara. Katarak ditandai dengan kekeruhan pada lensa mata dan penglihatan menjadi buram. Salah satu faktor yang dapat memengaruhi terjadinya katarak adalah indeks massa tubuh (IMT). Indeks massa tubuh yang tinggi dapat menyebabkan peningkatan stress oksidatif yang dipicu oleh kadar leptin yang tinggi. Prevalensi katarak yang ditemukan pada kategori overweight adalah 23\% dan pada kategori obesitas didapatkan sekitar 34\%. Pada indeks massa tubuh yang rendah dikaitkan dengan penurunan glutathione khususnya pada nukleus lensa. Terdapat penelitian yang menunjukan indeks massa tubuh memiliki hubungan dengan terjadinya katarak. Penelitian lainnya menyatakan indeks massa tubuh tinggi khususnya obesitas memiliki hubungan terjadinya katarak dengan prevalensi (RR 1.50, 95\% CI 1.24 1.81), (RR 1.52, 95\% CI 1.31-177) dan (OR 4.64, 95\% CI 2.8889-7.440). Sedangkan terdapat penelitian lain yang menyatakan tidak ada hubungan antara indeks massa tubuh tinggi dengan terjadinya katarak dengan prevalensi (OR 1.06, 95\% CI 0.80-1.40) dan (OR1.45, 95\%CI 1.261.66) dibandingkan dengan kelompok underweight. Kesimpulan yang didapat adalah terdapat hubungan antara indeks massa tubuh, khususnya pada kategori obesitas terhadap terjadinya katarak. Pencegahan yang dapat dilakukan agar terhindar terjadinya katarak adalah dengan mengontrol berat badan.
\end{abstract}

Kata kunci: indeks massa tubuh, katarak, obesitas

\author{
${ }^{1}$ Program Studi Kedokteran, \\ Fakultas Kedokteran Universitas \\ Trisakti, Jakarta, Indonesia \\ ${ }^{2}$ Departemen Ilmu Penyakit Mata, \\ Fakultas Kedokteran Universitas \\ Trisakti, Jakarta, Indonesia \\ Korespondensi: \\ Erlani Kartadinata \\ Departemen Ilmu Penyakit Mata, \\ Fakultas Kedokteran Universitas \\ Trisakti, Jakarta, Indonesia \\ Jalan Kyai Tapa (Kampus B) \\ Usakti, Grogol, Indonesia 11440 \\ Email: \\ erlani.kartadinata@trisakti.ac.id
}

J Biomedika Kesehat 2021;4(4):170177

DOI: $10.18051 /$ JBiomedKes.2021. v4.170-177

pISSN: 2621-539X / eISSN: 2621-5470

Artikel akses terbuka (open access) ini didistribusikan di bawah lisensi Creative Commons Attribution 4.0 International (CC-BY 4.0) 


\section{ABSTRACT}

\section{Relationship between body mass index and cataract}

It is estimated that as much as $42 \%$ of blindness cases in the world caused by cataracts come from Southeast Asia. Cataract characterized by cloudiness in the eye lens and blurred vision. One of the factors that can affect the occurrence of cataracts is body mass index (BMI). A high body mass index can cause increased oxidative stress triggered by high leptin levels. The prevalence of cataracts found in the overweight category was $23 \%$ and in the obesity category was around $34 \%$. A low body mass index is associated with a decrease in glutathione, especially in the lens nucleus. Several studies have shown that body mass index has a relationship with the occurrence of cataracts. Another study stated that high body mass index, especially obesity, had a relationship with the prevalence of cataracts (RR 1.50, 95\% CI 1.24-1.81), (RR 1.52, 95\% CI 1.31-177) and (OR 4.64, 95\% CI 2.8889-7.440). Another article stated that there was no relationship between high body mass index and the occurrence of cataracts with prevalence (OR 1.06, 95\% CI 0.80 - 1.40) and (OR 1.45, 95\% CI 1.26-1.66) compared to the underweight group. The conclusion is that there is a relationship between body mass index, especially in the obesity category and the occurrence of cataracts. Prevention that can be done to avoid cataracts is by controling body weight.

Keywords: body mass index, cataract, obesity

\section{PENDAHULUAN}

Katarak atau yang dikenal dengan kekeruhan lensa mata merupakan salah satu penyebab kebutaan terbanyak di Indonesia. ${ }^{(1)}$ Terdapat $50 \%$ kasus kebutaan yang disebabkan oleh katarak dan $90 \%$ diantaranya terjadi di Indonesia. ${ }^{(2,3)}$ Penyakit katarak merupakan salah satu penyebab dari gangguan penglihatan serta kebutaan tinggi di dunia (43\%), salah satunya di Indonesia setelah itu gangguan refraksi, seperti miopia, hiperopia, astigmatisme (33\%). ${ }^{(4)}$ Menurut World Health Organization tahun 2010, diperkirakan sebanyak $42 \%$ kasus kebutaan di dunia yang disebabkan oleh katarak berasal dari Asia Tenggara. Angka ini lebih tinggi daripada angka kejadian kebutaan karena katarak di Asia Selatan (41.7\%), Asia Timur (28.1\%) dan Asia Tengah (24.2\%). ${ }^{(5)}$ Pada tahun 2013-2014 dilakukan survei kebutaan dengan menggunakan metode Rapid Assessment of Avoidable Blindness (RAAB) di tiga provinsi yaitu di NTB, Jawa barat dan Sulawesi selatan, didapatkan prevalensi kebutaan pada masyarakat usia $>50$ tahun adalah dengan rata-rata sekitar 3.2 $\%$ dan penyebab utama dari kebutaan pada provinsi tersebut adalah katarak (71\%). ${ }^{(6)}$ Dan ditemukan prevalensi katarak pada metode RAAB di Jakarta pada tahun 2015 sekitar $81.9 \%$ (7) $^{(7)}$ Gangguan penglihatan yang disebabkan oleh katarak dapat menyebabkan kerugian terhadap ekonomi dan mengganggu kualitas hidup. ${ }^{(8)}$

Salah satu faktor yang berpengaruh pada kekeruhan lensa adalah indeks massa tubuh (IMT). IMT merupakan pengukuran standar dengan berat badan dalam kilogram dibagi dengan tinggi badan dalam meter dikuadratkan, hal ini dapat memengaruhi perkembangan katarak melalui beberapa mekanisme. Kemenkes membagi kategori berat badan menurut IMT menjadi beberapa kelompok. Seseorang dikatakan kurus jika memiliki IMT $<17.0$, normal 18.5-25.0, dan overweight $>25.0 .{ }^{(9)}$

Artikel ini bertujuan untuk memberikan informasi mengenai hubungan indeks massa tubuh dan katarak agar masyarakat dapat mencegah terjadinya katarak dan meningkatkan kesehatan mata serta kualitas hidup dengan mengendalikan indeks massa tubuh.

\section{Definisi katarak}

Katarak adalah pengembangan dari keadaan tidak tembus cahaya dalam lensa dengan ditandai adanya gangguan penglihatan (kabur atau mendung), penurunan penglihatan secara progresif. ${ }^{(11)}$ Menurut WHO, katarak adalah kekeruhan yang terjadi pada lensa mata dapat menghalangi sinar masuk ke dalam mata sehingga menyebabkan penurunan atau gangguan penglihatan. ${ }^{(12)}$ Katarak merupakan penyebab utama kebutaan di seluruh dunia. ${ }^{(13)}$ Terdapat beberapa jenis katarak yang dapat memengaruhi gangguan penglihatan pada masyarakat. Sebagian besar masyarakat yang terkena katarak, terjadi pada usia lebih dari 40 tahun. $^{(14)}$

\section{Etiologi dan faktor resiko}

Penyebab dan faktor resiko katarak adalah jenis kelamin, usia, hipertensi, merokok, diabetes melitus, status gizi, trauma mata. Perempuan memiliki insiden dan risiko lebih tinggi terjadi nya katarak dibandingkan dengan laki-laki, 
dikarena turunnya kadar estrogen pada masa menapause. ${ }^{(15)}$ Katarak umumnya terjadi karena proses penuaan. Katarak yang berkaitan dengan usia dapat didefinisikan sebagai katarak yang terjadi pada usia di atas 40 tahun $^{(16)}$ atau lebih dari 50 tahun, tidak terkait dengan trauma radiasi. Kejadian katarak akan lebih menjadi progresif dan lebih berat pada lansia. ${ }^{(15)}$ Peningkatan kadar plasma IL- 6 dan TNF- $\alpha$ pada individu dengan hipertensi, terkait dengan peradangan sistemik yang intens dengan peningkatan kadar protein C-reaktif dan dapat menyebabkan pembentukan katarak. Hipertensi menyebabkan perubahan pada kapsul lensa karena terganggunya transportasi ion kalium dalam sel epitel lensa. ${ }^{(15)}$

Hasil dari beberapa penelitian menunjukkan bahwa setiap individu yang pernah merokok dikaitkan dengan peningkatan risiko katarak terkait usia. ${ }^{(17)}$ Frekuensi merokok dapat dikaitkan dengan peningkatan kekeruhan pada mata. Senyawa yang terdapat pada asap rokok jika terhirup dapat memodifikasi komponen lenticular secara oksidatif. ${ }^{(15)}$ Kerusakan oksidatif memiliki peran penting dalam pembentukan katarak. Merokok dapat secara tidak langsung menimbulkan stres oksidatif pada lensa melalui penipisan antioksidan endogen, seperti vitamin $\mathrm{C}$, vitamin E dan $\beta$-karoten. Produk tembakau yang mengandung logam berat seperti timbal dan tembaga yang terakumulasi di lensa, dapat menyebabkan keracunan secara langsung. ${ }^{(18)}$

Kontrol diabetes mellitus yang buruk dapat terkait dengan pembentukan beberapa komplikasi sistemik dan okular termasuk penglihatan. ${ }^{(15)}$ Pembentukan katarak yang terkait dengan diabetes sering terjadi karena kelebihan kadar sorbitol (alkohol gula). ${ }^{(17)}$ Pengukuran status gizi dapat dilakukan dengan berbagai cara, salah satunya dengan indeks massa tubuh (IMT). Gizi yang seimbang mencangkup zatzat mikronutrien(vitamin dan mineral) dan makronutrien (lemak dan karbohidrat). Defisiensi nutrisi pada mikronutrisi dapat menyebabkan tejadi nya katarak..$^{(15)}$

Katarak dapat terbentuk setelah mata terkena benda tumpul, luka tembus ke mata dan masuknya benda asing yang sulit untuk dikeluarkan. Trauma ini akan menyebabkan kerusakan pada kapsul lensa mata sehinnga mempengaruhi kejernihan lensa. ${ }^{(15)}$

\section{Epidemiologi dan patofisiologi}

Pada tahun 2010, prevalensi katarak di Amerika Serikat adalah 17.1\%. Katarak paling banyak mengenai ras putih (80\%) dan perempuan. Menurut Riskesdas 2013, prevalensi katarak di Indonesia adalah $1.4 \%$ dengan responden tanpa batasan umur. ${ }^{(13)}$

Lensa adalah objek bikonvenks transparan, yang menyebabkan pembiasan dan memfokuskan cahaya ke retina. ${ }^{(19)}$ Pada lensa katarak secara karakteristik terdapat agregat-agregat protein yang dapat menghamburkan berkas cahaya. Perubahan protein pada lensa akan mengakibatkan perubahan warna lensa menjadi kuning atau coklat. Perubahan kimia dalam protein lensa dapat menyebabkan koagulasi, sehingga membuat pandangan menjadi buram serta menghambat jalannya cahaya ke retina. Katarak biasanya terjadi bilateral, namun memiliki kecepatan yang berbeda. Dapat terjadi pada orang yang memiliki penyakit sistemik seperti diabetes mellitus, distrofi otot, dermatitis atopik. Pada diabetes mellitus terjadi peningkatan glukosa dalam aqueous humor yang akan berdifusi pada lensa dan terjadi hidrasi sekunder pada lensa. (20)

Pada keadaan IMT yang tinggi (obesitas) dapat menyebabkan terjadinya denaturasi protein. Protein yang tertimbun pada lensa mengakibatkan koagulasi protein dan terjadi kekeruhan pada lensa. Kejadian ini dapat mengganggu transmisi sinar ke retina sehingga mengakibatkan pandangan menjadi kabur serta penurunan ketajaman penglihatan.

Pada usia lanjut dapat terjadi denaturasi dan kerusakan pada struktur protein lensa (crystalline), sehingga dapat mempengaruhi densitas, kekakuan, dan pigmentasi pada lensa. Kristalin akan mengalami agregasi dan berat molekul akan meningkat. Hasil agregasi protein mengakibatkan penurunan kecerahan, perubahan indeks refraksi lensa serta penyebaran sinar. Pada trauma mata dapat terjadi kerusakan pada kapsul lensa. Pada hal yang sudah dijelaskan tersebut dapat mengakibatkan kekeruhan pada kristalin lensa, semakin lama terjadi kekeruhan akan mengakibatkan formasi dari katarak. ${ }^{(20)}$

\section{Manifestasi klinis}

Lensa mata pada katarak terlihat tidak transparan yang diakibatkan oleh adanya 
kekeruhan, sehingga pupil terlihat menjadi warna putih keabu-abuan. ${ }^{(21)}$ Pasien katarak mengeluhkan gangguan penglihatan berupa penglihatan menjadi kabur, penglihatan warna terganggu, sensitivitas terhadap cahaya meningkat yang dapat memberikan kesan silau terutama pada malam hari saat berkendara, kesulitan untuk melihat pada malam hari, penglihatan menjadi ganda. ${ }^{(21,22)}$

\section{Penanggulangan katarak}

Pada tahun 2017, terdapat tiga aspek program penanggulangan terjadinya katarak yang dikeluarkan oleh pemerintah Indonesia, sebagai berikut: 1) dengan meningkatkan kualitas dan cakupan media, dapat dengan mudah mengedukasi masyarakat terkait katarak secara optimal; 2) dengan meningkatkan kualitas dan cakupan deteksi dini dan operasi katarak; 3) mendorong pelaksanaan untuk penanggulangan katarak di setiap daerah secara komprehensif dan inklusif, hal ini dilakukan dengan mempertimbangkan aspek demografi dan geografi serta prevalensi kebutaan akibat katarak. ${ }^{(7)}$

\section{Definisi Indeks massa tubuh}

IMT merupakan penanda kandungan lemak tubuh yang sering digunakan untuk menilai kelebihan berat badan atau obesitas. ${ }^{(23)}$ Menurut CDC, Indeks Massa Tubuh merupakan ukuran berat disesuaikan dengan tinggi, dihitung sebagai berat dalam kilogram dibagi dengan tinggi kuadrat dalam meter $\left(\mathrm{kg} / \mathrm{m}^{2}\right)$. (24) Penelitian yang telah dilakukan oleh Botti AB, Cueto FJAP, Monllor PAV dan kawan kawan menyatakan IMT berhubungan dengan ukuran lemak tubuh. ${ }^{(25)}$

\section{Faktor-faktor yang memengaruhi indeks massa tubuh}

Faktor-faktor yang mempengaruhi IMT adalah usia, jenis kelamin dan akitvitas fisik. Pada usia $\leq 50$ tahun IMT akan menurun, kemudian menetap pada usia sekitar 50 tahun dan pada usia $>50$ tahun IMT akan lebih tinggi. Beberapa penelitian menyatakan bahwa lebih banyak terjadi pada pria yang termasuk kategori kelebihan berat badan (overweight) dibandingkan wanita. Pria cenderung mengalami obesitas visceral dibandingkan wanita. ${ }^{(27)}$ Asupan energi yang berlebih dan tidak diimbangi dengan aktivitas fisik yang seimbang akan menyebabkan terjadinya penambahan berat badan. ${ }^{(28)}$

\section{Hubungan antara indeks massa tubuh dan katarak}

Katarak terus berkembang seiring waktu, menyebabkan kerusakan yang progresif. Katarak ditandai dengan adanya gangguan penglihatan, penurunan tajam penglihatan secara progresif, silau, perubahan persepsi warna dapat terjadi dengan intensitas berkurang. Katarak dipengaruhi beberapa faktor seperti usia, jenis kelamin, diabetes, hipertensi, indeks massa tubuh maupun trauma pada mata. Obesitas merupakan peradangan sistemik dengan peningkatan kadar protein C-reaktif dan sitokin proinflamasi serta peningkatan stress oksidatif yang disebabkan oleh sirkulasi yang lebih tinggi pada kadar leptin, hal ini berhubungan dengan pembentukan katarak. ${ }^{(29)}$

Selain itu, obesitas dapat memengaruhi stress osmotik dan protein lensa non enzimatik. (29) IMT yang tinggi juga dapat menyebabkan denaturasi protein. Protein yang tertimbun pada lensa mengakibatkan koagulasi protein dan terjadi kekeruhan pada lensa. Kejadian ini dapat mengakibatkan pandangan menjadi kabur serta penurunan ketajaman penglihatan. ${ }^{(20)}$ Menurut penelitian dari Sobti $S$ dan Sahni B, katarak dapat dipengaruhi indeks massa tubuh yang tinggi maupun rendah. Studi menurut Azim et al, menyatakan bahwa populasi dengan IMT tinggi $\left(>25 \mathrm{~kg} / \mathrm{m}^{2}\right)$ 4,64 kali lebih tinggi memiliki risiko terkena katarak. Penelitian Ye J et al melakukan riset pada populasi dengan IMT rendah, hasil yang didapatkan adalah seseorang yang memiliki risiko terkena katarak dengan tipe katarak kortikal ataupun kortikal nuklear. Hal ini dapat terjadi karena IMT rendah berhubungan dengan status sosialekonomi yang rendah dan nutrisi yang kurang. ${ }^{(30,31,32)}$ Kekurangan nutrisi dapat menyebabkan kerusakan pada kekebalan tubuh dan mengurangi antioksidan, seperti glutathione pada tubuh. Glutathione (GSH) berfungsi untuk melindungi sel lensa dari kerusakan antara oksigen reaktif dan radikal bebas. ${ }^{(33)}$ GSH memiliki peran penting dalam transparansi lensa dengan pengaturan keseimbangan elektrolit. Terdapat sistem GSH-dependent thioltransferase, termasuk enzim GSH-transferase yang dapat 
memperbaiki oksidasi protein lensa jika terdapat kerusakan. Enzim antioksidan ini dapat mencegah agregasi kristalin lensa dan mencegah terjadinya pembentukan katarak. ${ }^{(34)}$

\section{Indeks massa tubuh tinggi yang memengaruhi terjadinya katarak}

Penelitian yang dilakukan oleh Pan CW et al. menyatakan bahwa overweight dan obesitas merupakan masalah terbesar pada kesehatan masyarakat yang sangat berdampak pada sosial ekonomi, karena dapat menyebabkan berbagai macam penyakit seperti diabetes mellitus, penyakit kardiovaskular dan katarak. Pada obesitas proses pembentukan katarak dipengaruhi oleh peningkatan stress oksidatif yang terbentuk karena kadar leptin yang tinggi. ${ }^{(32,35)}$ Individu dengan obesitas memiliki jumlah peradangan sistemik yang tinggi dengan peningkatan kadar protein C-reaktif dan sitokin proinflamasi, hal ini dapat meningkatkan perkembangan katarak karena menyebabkan peradangan pada mata. Obesitas memengaruhi terjadinya peningkatan katarak nuklear, kortikal, dan posterior subscapular. Pada overweight terjadi peningkatan katarak posterior subscapular ${ }^{(35)}$

Penelitian yang dilakukan oleh Azim SF et al. menyatakan bahwa pada indeks massa tubuh yang tinggi, lingkar pinggang yang lebar dan rasio lingkar pinggang pinggul yang lebar dapat meningkatkan risiko terjadinya katarak. Keadaan obesitas dapat menyebabkan peningkatan adiposit sehingga menimbulkan peningkatan dari kadar leptin, hal ini dapat menyebabkan terjadinya katarak. Pembentukan katarak berhubungan dengan perubahan lipid pada serat lensa mata manusia. Pada serat lensa mata terdapat kolesterol sekitar $40 \%$ total lipid. Ketika kadar kolesterol tinggi pada membrane lensa, dapat menyebabkan peningkatan dari oksidatif dan dapat terbentuknya katarak. ${ }^{(32)}$ Penelitian yang dilakukan oleh Ye J et al, dengan metode meta-analisis didapatkan bahwa dari beberapa studi prospektif cohort indeks massa tubuh yang tinggi seperti overweight dan obesitas dapat memengaruhi terjadinya katarak. Overweight dikatakan dapat menyebabkan terjadinya peningkatan yang signifikan untuk terjadinya age-related cataract (ARC) terutama katarak dengan tipe posterior subscapular, dengan rasio sebesar 1.19 kali dibandingkan dengan indeks massa tubuh yang normal. Obesitas memiliki risiko tinggi terjadinya $\mathrm{ARC}$, dengan rasio sebesar 1.50 kali. Terjadinya peningkatan kadar leptin pada individu yang mengalami obesitas, dapat menyebabkan lensa menjadi keruh karena dengan adanya peningkatan kadar leptin dapat meningkatkan stress oksidatif. ${ }^{(30)}$

\section{Indeks massa tubuh rendah yang memengaruhi terjadinya katarak}

Penelitian yang dilakukan oleh Park S et al pada empat kelompok indeks massa tubuh, ditemukan bahwa indeks massa tubuh secara signifikan dapat menyebabkan terjadinya katarak kortikal, nuklear, dan tipe katarak lain pada pria. Penelitian ini menyatakan bahwa prevalensi katarak tertinggi (89.9\%) ditemukan pada kelompok underweight dan prevalensi katarak yang rendah ditemukan pada kelompok overweight pada pria. Sedangkan pada wanita dapat terjadi semua tipe katarak pada empat kelompok indeks massa tubuh. Hasil yang ditemukan bahwa indeks massa tubuh yang rendah secara signifikan dapat menyebabkan terjadinya katarak nuklear. Selain itu, peningkatan vitamin $\mathrm{B}_{2}$ pada wanita secara signifikan dapat meningkatkan risiko pembentukan katarak. Pada penelitian ini dilakukan pemeriksaan lebih luas lagi dengan dilakukan observasi pada pola hidup, kadar darah (gula darah puasa, insulin, trigliserid) dan asupan nutrisi pada empat kelompok indeks massa tubuh. Ditemukan prevalensi katarak rendah pada kelompok overweight pada kedua jenis kelamin dibandingkan dengan kelompok berat badan yang normal. Antioksidan dan asupan nutrisi, seperti vitamin $\mathrm{A}$ dan vitamin $\mathrm{B}_{2}$ pada kelompok overweight sangat tinggi. Antioksidan secara hipotesis digunakan sebagai faktor pelindung dari kerusakan lensa. Efek antioksidan sangat berpengaruh pada prevalensi katarak yang rendah pada kelompok overweight. ${ }^{(36)}$

Menurut penelitian yang dilakukan oleh Yoshida et al ditemukan bawah indeks massa tubuh yang rendah dapat dijadikan sebagai faktor risiko terjadinya katarak. Individu yang berada di negara berkembang dengan indeks massa tubuh rendah, malnutrisi atau asupan nutrisi yang tidak adekuat dapat memengaruhi kejernihan lensa yang mengakibatkan terjadinya katarak. Asupan energi yang rendah dalam jangka waktu yang lama dapat memengaruhi proteolitik pada lensa. ${ }^{(37)}$ 
Hal ini didukung oleh penelitian yang dilakukan oleh Sonowal SK et al bahwa kejadian katarak paling tinggi ditemukan pada pasien dengan indeks massa tubuh yang rendah $(<18.5 \mathrm{~kg} /$ $\mathrm{m}^{2}$ ) dengan prevalensi $35.59 \%$, sedangkan pada kategori overweight didapatkan sekitar $15.38 \%{ }^{(38)}$ Dengan terjadinya malnutrisi dapat menyebabkan peningkatan dari stress oksidatif sehingga terjadi pembentukan katarak. Insiden dan tingkat keparahan katarak nuklear terkait usia, dikaitkan dengan penurunan glutathione khususnya pada nukleus lensa, sehingga dapat menyebabkan terjadinya agregasi protein dan hilangnya transparansi lensa. ${ }^{(38,39)}$

\section{Pencegahan katarak}

Terdapat beberapa hal yang dapat mencegah atau menghambat progresifitas terjadinya pembentukan katarak, seperti nutrisi. Telah diketahui bahwa diet tinggi buah, sayuran, vitamin $\mathrm{C}$ dan vitamin $\mathrm{E}$ dapat dikaitkan dengan tingkat penyakit yang lebih rendah. Asupan buah dan sayuran yang tinggi dapat mengurangi terjadinya katarak. ${ }^{(40)}$ Pola makandengan mengkonsumsi daging dan produk susu dalam jumlah yang tinggi pada kedua jenis kelamin, dapat meningkatkan terjadinya pembentukan katarak dibandingkan dengan orang yang vegetarian. ${ }^{(41)}$ Mengkonsumsi antioksidan vitamin dapat melindungi degenerasi lensa setelah terjadi oksidatif.(42) Vitamin C dapat ditemukan pada lensa dan aqueous humor dengan konsentrasi yang ditemukan di dalam plasma. Askorbat dikenal sebagai antioksidan yang paling efektif dan tidak beracun pada sistem mamalia. Pengurangan askorbat dalam lensa yang dipengaruhi oleh usia dapat memengaruhi fungsi lensa. ${ }^{(43)}$

Vitamin E merupakan antioksidan yang larut dalam lemak dan melakukan diet vitamin E dan mengkonsumsi suplemen vitamin E, dapat mengurangi terjadinya katarak. Tetapi dinyatakan oleh Weikel KA et al. bahwa dengan diet vitamin E lebih efektif dibandingkan mengkonsumsi suplemen. ${ }^{(43)}$ Vitamin E dapat menghambat oksidasi lipid dan menstabilkan membran sel lensa serta dapat memengaruhi regenerasi askorbat dalam lensa. ${ }^{(44)}$

Berdasarkan artikel penelitian yang dianalisis pada penulisan literatur ini didapatkan bahwa indeks massa tubuh yang tinggi dan rendah dapat mempengaruhi terjadinya katarak, maka dari itu perlu edukasi kepada masyarakat mengenai pengendalian berat badan untuk menjaga kesehatan mata dan terhindar dari terjadinya katarak.

\section{KESIMPULAN}

Berdasarkan hasil analisis dari beberapa artikel penelitian yang telah dilakukan, didapatkan perubahan pada lensa mata dapat dipengaruhi oleh indeks massa tubuh. Indeks massa tubuh yang memiliki pengaruh tinggi terjadinya katarak adalah obesitas dengan prevalensi sebesar RR 1.50-1.52 kali dan OR 4.64 kali. Terjadinya katarak pada obesitas dipengaruhi oleh peningkatan stres oksidatif akibat oleh kadar leptin yang tinggi. Pencegahan yang dapat dilakukan untuk mengurangi resiko terjadinya kekeruhan pada lensa adalah dengan melakukan diet sehat dan mengonsumsi suplemen vitamin. Hal lain yang dapat dilakukan masyarakat adalah dengan melakukan pengendalian berat badan dengan tetap menjaga indeks massa tubuh yang normal (18.5$25.0 \mathrm{~kg} / \mathrm{m}^{2}$ ). Dalam penulisan literatur ini, penulis menyarankan untuk penelitian selanjutnya dapat dilakukan penelitian pada indeks massa tubuh dan pola makan ataupun nutrisi yang dikonsumsi oleh penderita katarak. Hal ini untuk mengetahui pengaruh pola makan atau nutrisi pada penderita katarak.

\section{REFERENSI}

1. Pusat Data dan Informasi Kementerian Kesehatan RI. Situasi gangguan penglihatan dan kebutaan. Jakarta: Kemenkes RI; 2014

2. Mo'otapu A, Rompas S, Bawotong J. Faktor-Faktor yang berhubungan dengan kejadian penyakit katarak di poli mata RSUP Prof.Dr.R.D.Kandou Manado. E-journal Keperawatan. 2015;3(2):1-6

3. Pascolini D, Mariotti SP. Global estimates of visual impairment. Br J Ophthalmol. 2012;96(5):614-8. doi: 10.1136/bjophthalmol-2011-300539

4. Royal National Institute of Blind People. Cataract statistics \& resources [Internet]. Royal National Institute of Blind People; 2014. Available from https://www.lasereyesurgeryhub.co.uk/cataractstatistics

5. Lee CM, Afshari NA. The global state of cataract blindness: A systemic review. Curr Opin Ophthalmol. 2017;28(1):98-100. doi:10.1097/ ICU.0000000000000340

6. Kementerian Kesehatan Republik Indonesia. Katarak penyebab tertinggi kebutaan di Indonesia [Internet]. Jakarta: Kementerian Kesehatan Republik Indonesia; 2019. Available from: http:// www.p2ptm.kemkes.go.id/kegiatan-p2ptm/pusat-/ katarak-penyebab-tertinggi-kebutaan-di-indonesia

7. Kementerian Kesehatan RI. Peta jalan 
penanggulangan gangguan penglihatan di Indonesia Tahun 2017-2030. Kementerian Kesehatan RI; 2018.

8. Garg P, Mullick R, Nigam B, et al. Risk factors associated with development of senile cataract. Era's Lucknow Medial College and Hospital India. 2020;5. doi: 10.5603/OJ.2020.0005

9. Kementerian Kesehatan RI. Tabel batas ambang indeks massa tubuh [Internet]. Kementerian Kesehatan RI; 2019. Available from http://www. p2ptm.kemkes.go.id/infographic-p2ptm/obesitas/ tabel-batas-ambang-indeks-massa-tubuh-imt

10. Iqbal F, Khan HA, Khalil I, et.al. Effect of weight and height on intraocular pressure: Research Article. MedCrave. 2019;9(2):34-5

11. Aini AN, Santik YDP. Kejadian katarak senilis di RSUD Tugurejo. HIGEIA. Universitas Negeri Semarang. 2018;2(2):295-306

12. World Health Organization. Universal Eye Health [Internet]. Who: 2013. Available from: https:// www.who.int/blindness/AP2014_19_English.pdf

13. Astari P. Katarak: Klasifikasi, tatalaksana, dan komplikasi operasi. Yogyakarta: Fakultas Kedokteran Universitas Gadjah Mada; 2018

14. Alimaw YA, Hussen MS, Tefera TK. Knowledge about cataract and associated factors among adults in Gondar Town Northwest Ethiopia. PLoS One. 2019;14(4):1-10. doi: 10.1371/journal. pone.0215809

15. Gupta VB, Rajagopala M, Ravishankar B. Etiopathogenesis of cataract: An Appraisal. Review Article. 2014;62(2):103-9. doi: 10.4103/03014738.12141

16. Hadini MA, Eso A, Wicaksono S. Analisis faktor risiko yang berhubungan dengan kejadian katarak senilis di RSU Bahteramas tahun 2016. 2016;3(2):256-67

17. Hamidi MNZ, Royadi A. Faktor-faktor yang berhubungan dengan terjadinya katarak senilis pada pasien di poli mata RSUD Bangkinang. Jurnal Ners. 2017;1(1):126-36

18. Ye J, He J, Wang C, et al. Smoking and risk of age-related cataract: A meta-analysis. invest. Ophthalmol. Vis. Sci. 2012;53(7):3885-95. doi: 10.1167/iovs. 12-9820.

19. Alshamrani AZ. Cataracts pathophysiology and managements. King Abdulaziz University. Egypt. J. Hosp. Med. 2018;70(1):151-4

20. Nartey A. The Pathophysiology of cataract and major interventions to retarding its progression. MedCrave. Ghana: Department of Optometry and Visual Science, Kwame Nikrumah University of Science and Technology. 2017;6(3):76-7. doi: 10.15406/aovs.2017.06.00178

21. Ilyas S, Yulianti SR. Ilmu Penyakit Mata. Jakarta: Fakultas Kedokteran Universitas Indonesia; 2014

22. American Optometric Association. Cataract [Internet]. American Optometric Association; 2020. Available from: https://www.aoa.org/ patients-and-public/eye-and-vision-problems/ glossary-of-eye-and-vision-conditions/cataract

23. Jayusfani R, Afriwardi, Yerizel E. Hubungan IMT (Indeks Massa Tubuh) dengan ketahanan (Endurance) kardiorespirasi pada mahasiswa pendidikan dokter Unand 2009-2012. Artikel Penelitian. Universitas Andalas. 2015;4(2):410-3

24. Centers for Disease Control and Prevention. Body Mass Index (BMI) [Internet]. CDC; 2020. Available from: https://www.cdc.gov/healthyweight/ assessing/bmi/index.html
25. Botti AB, Cueto FJAP, Monllor PAV, et al. International BMI-for-age references underestimate thinness and overestimate overweigth and obesity In Bolivian adolescents. Nutricion Hospitalaria. 2010;25(3):428-36. doi: 10.3305/nh.2010.25.3.4364

26. Utami D, Setyarini GA. Faktor-Faktor yang mempengaruhi indeks massa tubuh pada remaja usia 15-18 Tahun Di SMAN 14 Tangerang. Jurnal Ilmu Kedokteran Dan Kesehatan. 2017;4(3):20813

27. Kusuma BJ, Pinandita T. Rancangan bangun aplikasi mobile perhitungan indeks massa tubuh dan berat badan Ideal. Universitas Muhammadiyah Purwokerto; 2011.

28. Ariani NL, Masluhiya S. Keterkaitan aktivitas fisik dengan indeks massa tubuh (IMT) Siswa SD Kota Malang. Jurnal Care. 2017;5(3):457-65

29. Mohammadi SF, Afarideh M, Mehrjardi HZ, Mirhadi S. Obesity and density of the crystalline lens: revisiting a growing dilemma. Research Article. Biomedicine Hub. 2017;2:2-6. doi: 10.1159/000454979

30. Ye J, Lou LX, He JJ, et al. Body mass index and risk of age-related cataract: A meta-analysis of prospective cohort studies. China: Departement of Ophthalmology, Hospital of Zheijang University. PLoS One. 2014;9(2):1-7.

31. Sobti S, Sahni B. Cataract among adults aged 40 years and above an a rural area of jammu aistrictlin India: Prevalence and risk-factors. Original Article. IJHBR. 2013;1(4):284-93

32. Azim AF, Akhter QS, Akter T, et.al. Obesity and dyslipidemia: Risk factors for development of senile cataract. J Bangladesh Soc Physiol. 2018;13(1):29-33. doi: 10.3329/jbsp.v13i1.37846

33. Alhamdan AA, Alsaif AA. The nutritional, glutathione and oxidant status of elderly subjects admitted to a university hospital. Saudi J Gastroenterol. 2011;17(1):58-63. doi: 10.4103/1319-3767.74474

34. Heruye SH, Maffofou Nkenyi LN, Singh NU, et al. Current trends in the pharmacotherapy of cataracts. Pharmaceuticals (Basel). 2020;13(1):15. doi: 10.3390/ph13010015

35. Pan CW, Lin Y. Overweight, obesity, and agerelated cataract: A Meta-analysis. Optom Vis Sci. 2014;91(5):478-483. doi: 10.1097/ OPX.0000000000000243

36. Park S, Kim T, Cho S, et.al. Association between cataract and the degree of obesity. Optom Vis Sci. 2013;90(9):1019-27. doi: 10.1097/ OPX.0b013e31829cae62

37. Yoshida $\mathrm{M}$, Inoue $\mathrm{M}$, Iwasaki $\mathrm{M}$, et al. Association of body mass index with risk of age-related cataract in a middle-aged Japanese population. Environ Health Prev Med. 2010;15:367-373. doi: 10.1007/ s12199-010-0153-2

38. Sonowal SK, Jyoti Kuli J, Gogoi G. A Study of prevalence and risk factors of senile cataract in tea garden community in Dibrugarh district, Assam, India. IJSR. 2016; 5(3):388-98

39. Kumar, D, Lim, JC, Donaldson PJ. A Link between maternal malnutrition and depletion of glutathione in the developing lens: A possible explanation for idiopathic childhood cataract. Clin Exp Optom. 2013;96(6):523-28. doi:10.1111/cxo.12076

40. Braakhuis AJ, Donaldson CI, Lim JC, et al. Nutritional strategies to prevent lens cataract: Current status and future strategies. Nutrients. 
2019;11(5):1186. doi:10.3390/nu11051186

41. Appleby PN,Allen NE, Key TJ. Diet, vegetarianism, and cataract risk. Am J Clin Nutr. 2011;93(5):112835. doi: 10.3945/ajen.110.004028

42. Wei L, Liang G, Cai C, et al. Association of vitamin $\mathrm{C}$ with the risk of age-related cataract. Acta Ophthalmol. 2016;94(3):170-6.doi: 10.1111/ aos. 12688

43. Weikel KA, Garber C, Baburins A, et.al. Nutritional modulation of cataract. Nutr Rev. 2014;72(1):3047. doi: 10.1111/nure. 12077

44. Zhang Y, Jiang W, Xie Z, et al. Vitamin E and risk of age-related cataract. Public Health Nutr. 2015;18(15):2804-14. doi: 10.1017/ S1368980014003115 